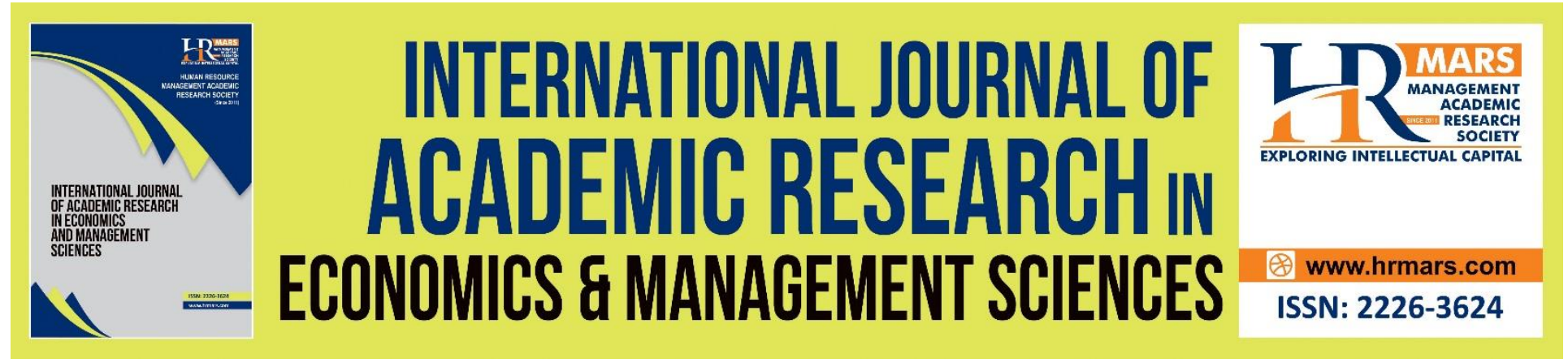

\title{
Higher Educational Opportunities for Underprivileged Community Via Waqf Education Financing Models
}

Sayuti Ab Ghani, Mohd Mahzan Awang, Ahmad Fahimi Amir, Redwan Yassin, Jamsari Alias

To Link this Article: http://dx.doi.org/10.6007/IJAREMS/v10-i2/10201

DOI:10.6007/IJAREMS/v10-i2/10201

Received: 01 April 2021, Revised: 29 April 2021, Accepted: 19 May 2021

Published Online: 20 June 2021

In-Text Citation: (Ghani et al., 2021)

To Cite this Article: Ghani, S. A., Awang, M. M., Amir, A. F., Yassin, R., \& Jamsari, A. (2021). Higher Educational Opportunities for Underprivileged Community Via Waqf Education Financing Models. International Journal of Academic Research in Economics and Managment and Sciences, 10(2), 68-78.

Copyright: @ 2021 The Author(s)

Published by Human Resource Management Academic Research Society (www.hrmars.com)

This article is published under the Creative Commons Attribution (CC BY 4.0) license. Anyone may reproduce, distribute, translate and create derivative works of this article (for both commercial and non-commercial purposes), subject to full attribution to the original publication and authors. The full terms of this license may be seen

at: http://creativecommons.org/licences/by/4.0/legalcode

Vol. 10, No. 2, 2021, Pg. 68 - 78

http://hrmars.com/index.php/pages/detail/IJAREMS

JOURNAL HOMEPAGE

Full Terms \& Conditions of access and use can be found at http://hrmars.com/index.php/pages/detail/publication-ethics 


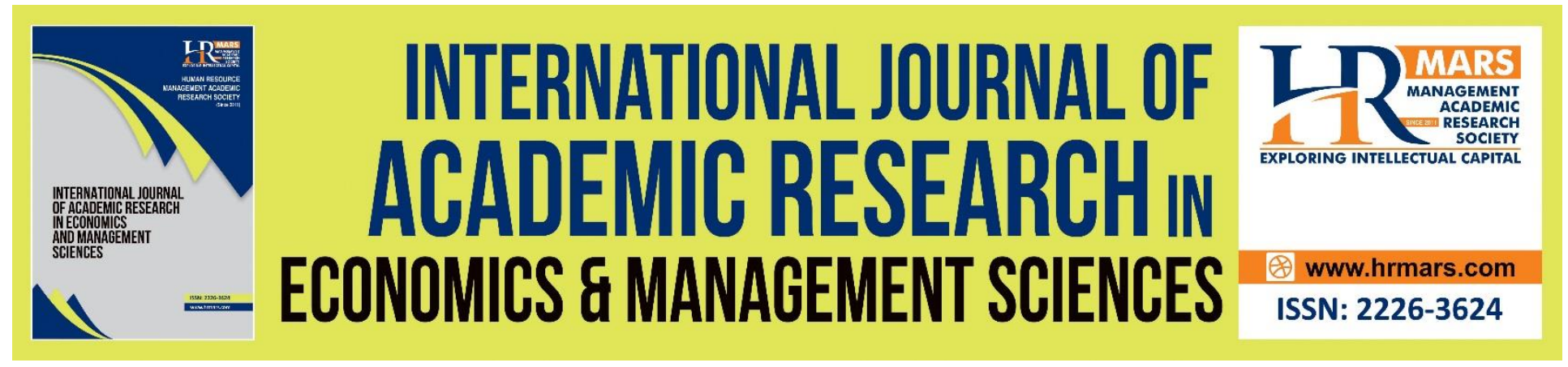

\title{
Higher Educational Opportunities for Underprivileged Community Via Waqf Education Financing Models
}

\author{
Sayuti Ab Ghani \\ National Defence University of Malaysia, MALAYSIA \\ Mohd Mahzan Awang \\ The National University of Malaysia, MALAYSIA \\ Email:mahzan@ukm.edu.my \\ Ahmad Fahimi Amir, Redwan Yassin \\ National Defence University of Malaysia, MALAYSIA \\ Jamsari Alias \\ The National University of Malaysia, MALAYSIA
}

\begin{abstract}
This article discusses the Waqf Education Model especially on the concepts, the implementation of Waqf funds, Waqf fund management and its distribution. A documentary analysis was carried out to extract any relevant information on Waqf education. Waqf education has been found to be an important instrument for educational development. The result of the document analysis shows that Waqf education can form a collaborative network in the effort to develop educational institutions between the members of the community and education management especially higher education in Malaysia. It is suitable for establishing a strong financial support for underprevilaged communities. Among the biggest contributions of Waqf education is that it can reduce the government's burden in financial expenses and assist the students who are facing financial problems in institutions of higher learning. It is evident that students gained many benefits through the distribution of Waqf education. Hence, the Waqf education model is an alternative for higher education financing that is vital and capable of being applied worldwide. Keywords: Higher Education, University, Waqf Education, Financing, Management, Community

Introduction

Various approaches have been taken by governments throughout the world in order to strengthen public higher learning institutions (PHEIs) to improve the quality of education. It is
\end{abstract}


evident in Malaysia's annual budget where a large allocation of government funds often allocated to financing various tertiary activities including management, teaching, learning, research and development (Gom'ah, 2012). Many efforts and measures were taken by the Government of Malaysia in enhancing the quality of education. Substantial government allocation is given to improve the quality of academic, research and development, as well as educational restructuring in line with the global economic demands. In the context of Malaysia, one of the key agendas and often given attention by the Ministry of Higher Education in Malaysia is to strengthen the financial position of higher learning institutions. Waqf is one of the ways to assist higher learning institutions in generating income and the benefits can be used for the purpose of improvement and progress of national education (Ali \& Wahid, 2014). Hence, the establishment of the Waqf management centre for all public institutions of higher education has been proposed.

\section{Issues on Financing Higher education}

The World Bank (2020) reported that more than $21 \%$ of government expenditure is on tertiary education, which is huge. Due to the global economic changes, universities have been urged to innovate their financial management as well as finding diverse resources to finance themselves. Selingo (2013) has reported that a lot of higher learning institutions in the United States faced financial and funding problems that contributed to the risk of them being shut down. In fact, university merger was also proposed to reduce costs and cover its financing. The funding problem also gives pressure to the university to cut down the number of staff, reduce costs, make operational restructuring and review the academic courses offered. One issue is the economic value related to the field of social sciences that is struggling with the job market demand. An initiative of giving more autonomy to the university to generate fund has been made, however, the university's financial problem remains a problem to the the university's top management. This situation has led to a study on alternative models in the financing of higher education in public universities. The question arises; how long will the Government be able to bear the burden of financing the cost of education that continue to increase from time to time? This is where Waqf education can play its role in taking over the government's burden in reducing the cost of education.

\section{Welfare and Endowment Education Fund}

Majority of universities in the world are practicing the concept of endowment for education as an instrument of empowering public higher education. The implementation of endowment for education in many universities worldwide is through sponsorship given to outstanding students amongst the socio-edonomic underprivileged. The implementation of endowment for education in most universities in the world is through private company contributions, individuals and others. This is evident when university development such as Harvard, Oxford, Cambridge, Yale and Stanford were done through this method (Yusof et al., 2014), (Othman, 2005). This endowment financing model is also practiced in all public universities in Malaysia, which has a similar number of common features as Waqf model. Waqf education is not a new thing because there are similarities between endowment, welfare and Waqf and it has long been implemented by several Islamic and Western countries.

In Malaysia, the principal goal in the establishment of public university Waqf Centre is to cater for the financial needs of underprivileged students to pursue their education in Malaysia. Public 
universities are given autonomy status to generate their own income to find funds to cover the cost of higher education (Awang et al., 2013). Under the Malaysian Education Development Plan 2015 - 2025 (Higher education), the government has given an incentive to the establishment of the endowment and Waqf fund by encouraging contribution to higher education at the early stages of its establishment through the provision of matching fund for higher education institutions. In order to drive continuous excellence in the national Higher education system, Waqf instruments are deemed suitable to be implemented to solve these problems. In order to provide guidelines to develop and manage the Waqf and endowment funds, the Ministry of Higher Education has produced a book on Enhancing University Income Generation, Endowment and Waqf Playbook (UniTP Purple Book). The book assists the public universities to generate funds and manage commercial public universities' activities through Waqf and endowment to be implemented more effectively (Mahamood et al., 2018).

In Islamic civilization, endowment in education has seen tremendous success. The introduction of the Waqf model of education in Islamic civilization became the pillar to rapid development of knowledge expansion in most of the developed Islamic countries. Higher education has evolved in tandem with the progress of Waqf in Islamic civilization. Waqf funds do not only help the development of Islamic education but also contributed to the development of other noneducation areas. This is proven with the success of the education system in Egypt. Al-Azhar University was built using Waqf cash fund and it had invested most of its Waqf cash funds to build storage warehouses in the Suez Canal. In addition, Al-Azhar University has also lent its Waqf cash fund to the Egyptian government. The sustainability of Al-Azhar University has proven the effectiveness of Waqf cash funds in the development of educational institutions (Ibrahim et al., 2013). Apart from that, the implementation of Waqf also occurred during the age of the Ottoman empire in providing various economic development activities to the society such as education, health, welfare and other activities that benefited the community (Cizakca, 1995). These are some of the roles Waqf funds are capable of where benefits are enjoyed by the society regardless of religion, culture and language, if they are eligible. Hence, Waqf education can provide valuable contribution to higher education.

Higher education in Malaysia has becoming more developed with the increase in the number of public higher education institutions and private higher education institutions (Awang et al., 2014). The public higher education institutions (Malaysian public universities) are clustered into three categories, namely: Research University, Comprehensive University and Focused University (technical, education, management and defence). To date, there are 20 public universities in Malaysia with the sub-categories of Research University $(\mathrm{N}=5)$, Comprehensive University $(\mathrm{N}=$ 4), and Focused University $(N=11)$. Almost all of these universities have established and implemented their respective Waqf education. The Waqf plan for higher educational institutions proved to have a place in Malaysia with the establishment of University Islam Malaysia (IIUM) located in Cyberjaya, the first university as a result of the implementation of the Waqf education. It was the first and only university to be established under the auspices of the Malay Rulers ' Council on 12 October 2010. IIUM is regarded as the pioneer of national Waqf education and will provide a guide for the establishment of Waqf higher education institutions in the future (Taib et al., 2017; Hashim et al., 2016). 


\section{Objectives and Research Methodology}

This study aims to understand the Islamic financing of higher education based on the concept of Waqf as an alternative model. This study will explain in-depth regarding the Waqf concept of education, the implementation of Waqf funds, as well as its fund management and distribution. This study uses the library research approach - collecting and analysing information from secondary data in the form of formal documents, journals, malaysian institutions' official magazines and academic papers (Hashim et al., 2016), written in Arabic, Bahasa Malaysia and English. Keywords used are Waqf and education funding. These secondary data collections involved direct references from Waqf institutions in Malaysia, Waqf centre at public universities and Islamic finance office in Malaysia. To get the right information from all of these institutions, data collection technique of document review and snowball sampling are used to obtain needed information. All data obtained will go through a careful analytical process and will be developed in a systematic manner.

\section{Research Findings and Discussion}

The focuses of this study are: (1) The concept of Waqf education, (2) The implementation of the Waqf fundraising (3) Management and Distribution of Waqf education.

\section{The Concept of Waqf Education}

Based on the document examined, it can be concluded that the word 'Waqf' originated from the Arabic word which means "to stop", "to prevent" and "to hold". The provider of Waqf fund is meant to provide property or land for religious needs such as land for burial, for the construction of mosques, surau and madrasah for public use. Muslim scholars have interpreted the meaning of welfare in the above sentence as 'Waqf', that it is the only worship that can be categorized as a charity deed because the reward acquired by the endower is of constant reward - a reward acquired even after the endower has died and as long as the endowed property remains and is utilized (Siti Mariam, et.al, 2014). This practice can create a sense of responsibility, welfare and caring society (Awang, Ahmad, Mumpuniarti \& Rahman 2019) as encouraged by Islam.

Significant difference between Waqf models and endowment and welfare fund in the empowerment of education is in the aspect of religion. Rahman (2004) stated that "Waqf means freezing the capital or property, and not disposing of it by selling, giving or inheriting, or in any other way, so that any income or earnings are to be disposed of in the manner dictated by the person who initiated the waqf, for charitable purposes and the like ... (meanwhile, endowment) ... is a gift or bequest means giving up possession of some wealth to someone who will benefit from it and who has full power of disposal over it". In most Asian countries, the socio-religious capital has a great role in mobilizing educational institutions. The Waqf model is one of the real estate management instruments and development in Islam that provides the rewarding concept of the hereafter rewards. Thus, many Waqf centres have been established in the Asian countries including Malaysia. In addition, research shows that the level of readiness and involvement of society in Malaysia in these charitable activities are well received by the majority of the Muslim community (Awang et al., 2011).

Waqf education is a model of education funding that forms a charitable practice through a sincere contribution that is extended by various parties for educational purposes. Waqf education can be an immovable property (such as land, building), goods, assets, and finance given 
to the education sector, including institutions of higher learning. It can be given one-off or on a continuous basis for public interest and benefits. The Waqf education was created for continuity of economic development especially in the field of education and the creation of continuous funds without relying on funds given by the government. The potential of Waqf in efforts to develop the economy of an educational institution such as university is yet to be believed and practiced in Malaysia (Taib et al., 2017). Apart from that, Mahamood \& Rahman (2014) explains the existence of Waqf education has existed through the construction of mosques, surau, madrasah and huts that were done by the local community and by the immigrants migrated to the country. This also includes contribution from the government and the state leaders in developing Islamic-based education institutions. The concept of Waqf education according to Mahamood et al. (2018a) refers to a financing for educational purposes which involves the provision of a property that can be enjoyed or benefited from a funder whether of an individual, an institution or a government to a higher educational institution for any educational purpose for the benefit of the institution and all its citizens in accordance to Islamic law and any currently enforced law.

Revisions to the Ministry of Higher Education Blueprint has found that the government has placed Waqf education as one of the main sources of higher education financing in Malaysia, namely academic and research programmes (academic programmes, specialist and short courses), research and commercialisation, fund-raising, asset monetisation, Waqf (Corporate alWaqf, Alumni al-Waqf, Public al-Waqf and Waqf Government), Conventional Endowment (philanthropic - Corporate donors, Alumni donors \& public donors; Government funding), Financial Management Activities/Investment, and Corporate alliances. The Waqf contribution in the education sector in Malaysia began with the private Islamic school (huts), followed by Madrasah or the Arabic-stream school which subsequently expanded to higher education institutions. Waqf educational institution is an organisation or institution established through the contribution of the Muslim community or built on a piece of land or a building endowed for Islamic education purposes. Its main goal is to gain God's love, and to produce righteous Islamic communities, believers (Mukmin) and devoutly religious (Muttaqin) (Latiff et al., 2008).

Analysis on official documents, journals and magazines related to Waqf education in Malaysia explained the early history of Waqf in Malaysia. The Waqf of education in Malaysia began at the hut schools (Sekolah Pondok) which then led to the creation of Madrasah schools and subsequently Community Religious School or Sekolah Agama Rakyat (SAR). The endowment of Islamic educational institutions can be divided into three categories. Firstly, the Community Religious School (SAR). It receives financial resources from the federal government, state or State Religious Council and is administered by the citizens or teachers and is registered as a private school under the Waqf title (whether as a reserve religious school or private Waqf). All costs and expenses incurred by the owner. Secondly, the State Religious School (Sekolah Agama Negeri) (SAN) which is fully funded by the State Government and administered by the State Government through the state Religious Council. Thirdly, Sekolah Agama Rakyat (SAR) under the Administration of State Religious Council and Zakat. The second and third category, are State Government-assisted schools and controlled by MAIN (State Islamic Religious Council) as its trustee and administered solely by MAIN and placed under the Committee of Religious Schools (Salleh \& Rahman 2014). 
In an article on the governance of Waqf education, Ahmad et al. (2014) highlighted the needs of WAQF education in public and private higher education institutions to establish a special unit of Waqf management which serves to collect funds through Waqf, Hibah, donation, will and tabarru'. It acts as the main source to finance the physical development and financing of students who are in need. A Governance for Waqf Model according to Ahmad et al. (2014) is as follows: (a) establishment of a body or foundation to implement a Special Waqf for Education concept; (b) forge a close cooperation with the State Islamic Religious Council in accordance with the Council's capacity as a ' Sole Trustee ' based on the Act and Enactment, (c) the management of the higher educational institutions has the authority that acts as the body in managing the Waqf property (Nazir al-Awqaf), (d) the member of the Board of Directors (ALP) is determined by the management of the HEI (higher education institution), (e) responsible in managing students' welfare from the orphans, children whose family are below the rural and urban poverty line, the new converts and others, (f) obtained approval from MAIN (State Islamic Religious Council) as certified Amil Zakat (collector or distributor) with the privilege of receiving a specific percentage of the category of Asnaf (the poor) such as 'Amil, Faqir, poor and fi-Sabilillah, and (g) manage contributions from other sources such as hibah, tabarru' and will.

\section{Implementation of Education Waqf Fundraising}

The analysis of documents has also found a proposal to further strengthen the Waqf education using Cash Waqf concept to facilitate education funding through subsidies mechanism through reduction of fees or gifts. The Waqf Model for Higher Education Institution (HEI) is also not limited to the form of cash and property but also includes teaching, research and writing, books and teaching aids. The $\mathrm{HEl}$ is also recommended to establish a special institution to manage the Waqf and pursue in owning assets and land endowed by the Government or the public through negotiations. The HEI is also recommended to build a network with individuals or a reputable corporate company, in addition to working with the foreign Waqf foundation to obtain funds (Salleh \& Rahman 2014).

The collection of Cash Waqf funds is via subsidies mechanism through the reduction of fees or monetary gifts. The Waqf of HEI Model is also not limited to cash and property but also includes teaching, research and writing, books and teaching aids. The HEI is also recommended to establish a special unit to manage Waqf and puruse to owning assets and land endowed by the Government or the public through negotiations. The $\mathrm{HEl}$ is also recommended to build a network with individuals or a reputable corporate company, in addition to working with foreign Waqf foundation to obtain funds (Taib et al., 2017). Apart from that, Ghazali (2012) has proposed cash Waqf mechanism (liquid assets), Islamic Muamalat system applications such as takaful instruments, Islamic capital markets, sukuk (Islamic bond) and the utilisation of the Waqf funds itself to generate high profits in managing Waqf funds in Malaysia. In addition, Mustaffaa \& Muda (2014) has proposed in his writings that the implementation of Waqf of education in a higher education institution can be intensified with effective fund management, strong legislation, good governance, effective marketing, and identifying the appropriate Waqf management model to be applied.

If administrative management and fundraising of Waqf are not properly carried out, it can lead to Waqf education being perceived negatively. To strengthen and expand the Waqf education funds in the higher education institution in terms of form and collection of funds, Mahamood et 
al. (2018) lists the category of education Waqf, namely: (a) Cash Waqf -Waqf involving cash; (b) Shares Waqf - Waqf involving the sale of certain property units which were subsequently endowed; (c) Waqf shares - namely Waqf involving existing shares owned by the endower; d) Waqf Irsod -Waqf involving land from the government; (e) Corporate Waqf - Waqf involving an individual or corporate company; ( $f$ ) Financing from sukuk, crowd funding, ljarah financing and others deemed appropriate, and (g) Other resources deemed appropriate in accordance with Islamic law.

\section{Management \& Distribution Waqf Education}

The contribution of Waqf education to Malaysian public higher educational institutions is not to be disputed especially in assisting the students who are less fortunate from a financial standpoint. Based on study, there is no such thing as 'free' in education in Malaysia either at kindergarten, lower and secondary schools or higher educational institutions. Among the welfare provided are the postponement of payment or reduction of payments given to specific groups only. Waqf Educaiton opens a wide door for underprevilaged communities to get financial assistance to pay their tution fees at a university level. Based on the objectives of the establishment of special educational Waqf entities for public and private higher educational institutions, in order to reduce the burden of higher education costs, it is proposed that funds raised from the contribution of the community and corporate bodies will be used in accordance with the following distributions: (a) Students' financing and sponsorship $=40 \%$; (b) Development of infrastructures $=30 \%$, (c) investments $=20 \%$; (d) Management $=10 \%$. However, this percentage is up to each of the $\mathrm{HEl}$ to distribute them in accordance with methods and provisions based on their respective situations.

It is found that many mechanisms proposed for funding involve (a) direct financing (scholarship) from Waqf Fund; (b) intermediary with a corporate body for the scholarship award to outstanding students coming from financially-poor family; (c) Sponsorship of assets (e. g: Laptops). This can be done either using part of the Waqf fund or through a sponsor by a corporate body (to be advertised); and (d) giving discount of fees to outstanding students irrespective of their economic status, and the reduced fees were borne by the Waqf fund (Ahmad et al., 2014). In addition, Waqf fund also became one of the financial resources in the education sector which was used for the payment of teachers and staff salaries, building construction, scholarship allocations, purchase of textbooks and more (Atan et al., 2014). At the tertiary level, the Government will provide scholarships to individuals who excel in academic or even in curriculum only and in addition for students who had to apply for loan provided by the Government or private sector. In general, students who further their study either in a public or a private university all come from a different family background. However, majority of them come from a modest family that requires financial assistance to continue their study. Therefore, most students who studying in higher education institutions received financial assistance either from government or private agencies such as MARA (Majlis Amanah Rakyat), Public Service Department, The National Higher Education Fund, Zakat and so on. However, at the same time, they had to request additional assistance from their family to cover other ancillary costs. In this regard, this study tries to uncover the problems faced by most students of higher education institutions either involving public or private higher educational institutions (Ahmad et al., 2014). 
However, all the above education loans are subject to the family income. Based on interviews done on Education loans, the amount of loans received by each student is different and it depends on the family household income. Hence, some of them claimed the amount of loans received could only help to settle their tuition fees and they must find another alternative to support their studies in the university. This is where the importance of Waqf education helps meet the basic needs of every university student such as daily sustenance. As a result of the establishment and implementation of the Waqf centre in public higher educational institutions, there are significant benefits and contributions to the development of education in Malaysia. The implementation of Waqf education in the higher educational institutions can be intensified with effective fund management, strong legislation, good governance, increase marketing and identifying the appropriate Waqf management model to be applied. A special guideline for the management of Waqf education in the higher educational institution needs to be established and the Waqf management model needs to be designed as a reference to all higher educational institutions (Mustaffaa \& Muda, 2014)

\section{Conclusion}

Waqf education is an alternative funding model that is very significant and relevant to the development of today's education. Its application is not only applicable in Malaysia, but it can be practiced and adapted to other higher educational institutions in the world. This is because, the implementation of Waqf education involves public contributions to the development of educational institutions. The implementation of this Waqf education is an indirect sense of ownership and caring towards an educational institution. The help and sharing of community expertise on educational institutions will lead to excellence in universities. Public higher educational institutions should adopt a financial transparency especially since the expenditure undertaken is using public funds. The transparency will build confidence among the society members who contribute to the education fund and the development of the Waqf education fund can be further increased from time to time. In addition, public higher education institutions should be aware of the market needs and requirements in managing Waqf education fund so that it is always relevant, particularly based on updating policies and regulations set in the Waqf education. This is particularly important for the target group especially students who are less fortunate in order for them to benefit from the implementation of Waqf education. The Waqf education is seen to be very significance with today's poor economic environment which affects university's expenses and students' financial burden who are less fortunate to pursue their studies in public university. As a result, each public university must take a pro-active measure in enhancing their financial resources particularly in assisting the university students through the establishment and implementation of Waqf education. Waqf education is an excellent approach in providing comfort to the underprivileged students from financial standpoint and subsequently lift the image of national education. Waqf Pendidikan is appropriate in all contexts as it is a framework for sustainable community contributions to education. In the context of a country with a large Muslim community, the implementation of Waqf education becomes extremely important and relevant. It is a framework of social responsibility coded as a commendable practice in Islam. However, this does not mean that it is not suitable for non -Muslim communities. This is because the elements of Waqf education have actually been present in various education financing schemes. 
INTERNATIONAL JOURNAL OF ACADEMIC RESEARCH ECONOMICS AND MANAGEMENT SCIENCES

Vol. 10, No. 2, 2021, E-ISSN: 2226-3624 @ 2021 HRMARS

\section{Acknowledgement}

Thanks to funders: National Defence University of Malaysia (Grant code: NDUM/2019/GPJP/2/SSI/2) \& Faculty of Education, The National University of Malaysia (K016391)

\section{References}

Ahmad, W. A. W., Othman, M. M., Wahab, M. H. A., \& Shaharuddin, H. (2014). Waqf Educational Development in HEl: An Alternative to Reduce a Cost of Study (Pembangunan Waqaf Pendidikan Di IPT Malaysia: Satu Alternatif Untuk Mengurangkan Kos Pengajian), Seminar Waqf Iqlimi 2014, USIM.

Al-Munajjid, S. M. S. (2020). The difference between Waqf and Endowment/trust fund. Online accessed on $4^{\text {th }}$ April 2020: https://islamqa.info/en/answers/10646/the-differencebetween-waqf-and-endowmenttrust-fund

Ali, S. Z., \& Wahid, H. (Oktober 2014). The Roles and Imporantce of Waqf Education in Malaysian Higher Education Institutions (Peranan dan Kepentingan Dana Wakaf Institusi Pendidikan Tinggi di Malaysia), Proceeding of Persidangan Kebangsaan Ekonomi Malaysia ke-9 (PERKEM ke -9).

Atan, S. M., Wahab, N., Salleh, R. M., \& Sainan, Z. (2014). A Contribution of Waqf Property in Johore Educational Sector: A Review (Sumbangan Harta Wakaf dalam Sektor Pendidikan di Johor: Satu Tinjauan). Proceeding of the International Conference on Masjid, Zakat and Waqf (IMAF 2014) 1-2 December 2014, Kuala Lumpur, Malaysia.

Awang, M. M., Ahmad, A. R., Bakar, N. A., Ghani, S. A., Saad, C. P., Husin, S., Hashim, Z., Ibrahim, M. A. H., \& Alfitri. (2014). Examining gaps between students' expectations and experiences in a private university. Mediterranean Journal of Social Sciences. 5 (8), 396-396

Awang, M. M., Ahmad, A. R., Mumpuniarti., \& Rahman, A. A. A. (2019). Social Integration Practices among Multi-ethnic Youths. Kasertsart Journal of Social Sciemces. 40, 454-458

Awang, M. M., Ahmad, A.R., Bakar, N. A., Ghani, S. A., Yunus, A. N. M., Ibrahim, M. A. H., Ramalu, J. C., Saad, C. P., \& Rahman, M. J. A. (2013). Students' Attitudes and Their Academic Performance in Nationhood Education. International Education Studies. 6(11), 21-28

Awang, M. M., Yuousuf, M. I., \& Ghani, S. A. (2011). A Study of Socio-Religious Activities by Muslim Youth. European Journal of Social Sciences, 18(4), 596-601

Cizakca, M. (1995). Cash Waqfs of Bursa. Journal of the Economic and Social History of the Orient. 38 (3), 1555-1823

Gom'ah, A. (2012). Waqf and the Effect towards Economic Development (Wakaf dan Kesannya Dalam Pertumbuhan Ekonomi). Paper presented in Seminar Wakaf Menjana Ekonomi, 16 Julai 2012, Putrajaya, Malaysia.

Hashim, R., Ramli, R., Dahalan, N. F., Ismon, N Y., \& Romli, S. (2016). Investment Instruments to Generate Higher Education Institution Waqf Funding (Instrumen Pelaburan Bagi Penjanaan Dana Wakaf Institusi Pengajian Tinggi: Satu Tinjauan), Ulwan Ulwan Journal,

Hassan, N. C. (2007). Islamic Approach in Funding Management System: An Investigation (Sistem Pengurusan Dana Cara Islam: Satu Penelitian), Jurnal Pengurusan JAWHAR. 1 (2)

Ibrahim, H., Amir, A., \& Ariffin, T. (2013). Cash Waqf: An Innovative Instrument for Economic Development, International Review of Social Sciences and Humanities. 
Latiff, A. Z. A., Ramli, A. H., Ismail, C. Z., Sulaiman, K., \& Daud, N. M. (2008). Waqf, Management and Contribution towards Islamic Education in Malaysia (Wakaf, Pengurusan dan Sumbangannya Terhadap Pendidikan Islam di Malaysia), Paper of UPENA, UTM Shah Alam, Malaysia

Mahamood, S. M., \& Rahman, A. A. (2014). Waqf financing For Higher Education: Contemporary Funding Aplications in Some Selected Countries, in Mujani, W. K. (2014). eds. Pelestarian Institusi Wakaf Memperkasa Pendidikan Tinggi, Bangi: Fakulti Pengajian Islam UKM, Malaysia.

Mahamood, S. M., \& Rahman, A. A., \& Seman, A. C. (2018). Establishment of Higher Education Institutions based on Waqf in Malaysia: Proposal for Implementation Model (Pembentukan Institusi Pengajian Tinggi Berteraskan Wakaf Di Malaysia: Cadangan Model Pelaksanaannya). Jurnal Syariah, 26 (1), 1-22.

Mahamood, S. M., Rahman, A. A., \& Seman, A. C. (2018a). Challenges for Impelementing Waqf in Malaysian Public Higher Education: Analysis based on Malaysian Law (Cabaran Pelaksanaan Wakaf Universiti Awam di Malaysia: Analisis Menurut Perundangan Di Malaysia), KANUN: Jurnal Undang-undang Malaysia, 30(2)

Mustaffaa, M., \& Muda, M. Z. (2014). Waqf Management in Malaysian Higher Education Institutions: A Literature Review (Pengurusan Wakaf Pendidikan di Institusi

Othman, R. (2005). The Influences of Colonisation on the Perception and Practices of Wakaf, Jurnal IKIM. Kuala Lumpur: IKIM, Malaysia.

Rahman, A. A. A., Ahmad, A. R., Malek, J. A., \& Awang, M. M. (2016). Social participation and values acculturation through non-formal learning among urban residents of Putrajaya. Kajian Malaysia. 34 (2), 75-100

Rahman, M. (2004). Jurisprudence and Islamic Rulings: General and Transactions. London: MSA Publications.

Salleh, M., \& Rahman, N. S. A. (2014). Waqf Education in Malaysia: A Review (Wakaf Pendidikan di Malaysia: Satu Tinjauan). International Research Management and Innovation Conference 2014 (IRMIC2014) Kuala Lumpur, 17 - 18 November 2014

Selingo, J.J. (2013). Colleges Struggling to Stay Afloat. The New York Times, 12 April, 2013.

Taib, M. S. M., Mujani, W. K., Rozali, E. A., \& Khalid, K. A. T. (2017). Development of Waqf Higher Education in Malaysia (Perkembangan Wakaf Pendidikan Tinggi di Malaysia). International Journal of West Asian Studies, 9(1), 82-92

Wafa, S. M. G. (2012). Waqf Development in Higher Education Institutions (Pembangunan Wakaf di Institusi Pendidikan Tinggi), 3rd International Conference on Islam and Higher Education, Kuantan, Pahang, Malaysia.

Yusof, A. M., Omar, I., \& Johan, J. (2014). Endowment and waqf in higher education. Land Questions Aspect of Land Management and Development (eds.). Land Questions Aspect of Land Management and Development, page: 199. Johor: Muafakat Jaya Percetakan Sdn. Bhd 